\title{
Differences in the sensitivity of classically and alternatively activated macrophages to TAK 1 inhibitor-induced necroptosis
}

\author{
Zsófia Varga $^{1,2} \cdot$ Tamás Molnár $^{1,2} \cdot$ Anett Mázló ${ }^{1,2,3} \cdot$ Ramóna Kovács $^{1,2} \cdot$ Viktória Jenei $^{1} \cdot$ Krisztina Kerekes $^{4} \cdot$ \\ Attila Bácsi ${ }^{1} \cdot$ Gábor Koncz $^{1}$ (1)
}

Received: 10 January 2020 / Accepted: 17 April 2020 / Published online: 29 May 2020

(c) The Author(s) 2020

\begin{abstract}
Controlling the balance of pro-inflammatory M1 versus anti-inflammatory M2 macrophages may have paramount therapeutic benefit in cardiovascular diseases, infections, cancer and chronic inflammation. The targeted depletion of different macrophage populations provides a therapeutic option to regulate macrophage-mediated functions. Macrophages are highly sensitive to necroptosis, a newly described regulated cell death mediated by receptor-interacting serine/threonine-protein kinase 1 (RIPK1), RIPK3 and mixed lineage kinase domain like pseudokinase. Antagonists of inhibitors of apoptosis proteins (SMAC mimetics) block RIPK1 ubiquitination, while TGF-activated kinase 1 (TAK1) inhibitors prevent the phosphorylation of RIPK1, resulting in increased necroptosis. We compared the sensitivity of monocyte-derived human M1 and M2 cells to various apoptotic and necroptotic signals. The two cell types were equally sensitive to all investigated stimuli, but TAK1 inhibitor induced more intense necroptosis in M2 cells. Consequently, the treatment of co-cultured M1 and M2 cells with TAK1 inhibitor shifted the balance of the two populations toward M1 dominance. Blockage of either Aurora Kinase A or glycogen synthase kinase 3B, two newly described necroptosis inhibitors, increased the sensitivity of M1 cells to TAK1-inhibitor-induced cell death. Finally, we demonstrated that in vitro differentiated tumor-associated macrophages (TAM-like cells) were as highly sensitive to TAK1 inhibitor-induced necroptosis as M2 cells. Our results indicate that at least two different necroptotic pathways operate in macrophages and the targeted elimination of different macrophage populations by TAK1 inhibitor or SMAC mimetic may provide a therapeutic option to regulate the balance of inflammatory/anti-inflammatory macrophage functions.
\end{abstract}

Keywords Necroptosis $\cdot$ Macrophage $\cdot$ Inflammation $\cdot$ Cancer

Electronic supplementary material The online version of this article (https://doi.org/10.1007/s00262-020-02623-7) contains supplementary material, which is available to authorized users.

Gábor Koncz

konczgb@gmail.com

1 Department of Immunology, Faculty of Medicine, University of Debrecen, 1 Egyetem Square, Debrecen 4032, Hungary

2 Doctoral School of Molecular Cellular and Immune Biology, University of Debrecen, Debrecen, Hungary

3 MTA-DE Cell Biology and Signalling Research Group, University of Debrecen, Debrecen, Hungary

4 BBS Nanotechnology Ltd., Debrecen, Hungary

\section{Introduction}

Macrophages with highly polarized functions coexist in tissues throughout the body to ensure the modulation of immune responses. Traditionally, macrophages can be subdivided into classically activated M1 and alternatively activated M2 phenotypes. M1 cells provide the first line of immune defense and activate both innate and adaptive immunity, while M2 macrophages are responsible for the regulation of tissue regeneration, are involved in the clearance of apoptotic bodies and contribute to the immune suppression [1]. Controlling the balance of pro-inflammatory versus anti-inflammatory macrophages may have paramount therapeutic benefit in all the world's leading causes of death, such as in cardiovascular diseases $[2,3]$, infections [4], cancers [5, 6], chronic inflammation [7], diabetes [8] or autoimmune reactions [9].

The success of immunotherapy highlights the effectiveness of the immune system in tumor eradication. Tumors 
still develop in spite of the immune attack, because tumors are surrounded by immunosuppressive cells and can escape from immune surveillance by hampering the onset of an effective anti-tumor immune response [10]. The tumor microenvironment (TME) consists of various immune cells, where macrophages form one of the most abundant cell populations. Solid tumors manipulate macrophage recruitment and regulate macrophage differentiation. Reprogrammed tumor-associated macrophages (TAM) supports tumor formation through upregulation of angiogenesis, growth factor production or immunosuppression, and these cells also promote metastasis and increase drug resistance $[5,6]$, Unlike monocytes, macrophages have a long life span of months to years [11]. Accordingly, macrophages are relatively resistant to most apoptotic stimuli, but are highly sensitive to two newly described inflammatory forms of regulated cell death, necroptosis [12,13] and pyroptosis [14]. Necroptosis is a regulated event rather than an accidental cell death process in which the most critical contributors are receptor-interacting protein 1 (RIPK1) [15], RIPK3 [16] and mixed lineage kinase domain like pseudokinase (MLKL) [17]. Necroptosis is known to play an important role in the pathogenesis of many diseases, such as neurodegenerative or inflammatory disorders, gastrointestinal, cardiovascular and pulmonary diseases [18]. The critical receptors of macrophages such as death, pattern recognition, DNA binding, cytokine and adhesion receptors all have been identified as potential inducers of necroptosis [19]. Necroptosis can be activated when apoptosis is blocked and pro-necroptotic proteins are released from caspase-8-mediated inhibition [15]. Active caspase- 8 blocks the necroptotic mode [15] of action preferentially through the cleavage of RIPK1 [20], RIPK3 [21] and the cylindromatosis (CYLD) protein, which mediates deubiqutination of RIPK1 [22]. The ubiquitination of RIPK1 by inhibitors of apoptosis proteins (cIAPs) initiates cell survival [23]. The created ubiquitin network allows the activation of TGF-activated kinase 1 (TAK1), which mediates survival signals by (1) activating the NFKB and MAPK signaling pathways and thereby increasing the expression of several prosurvival molecules $[24,25],(2)$ preventing the interaction between RIPK1 and cell death-related molecules [26], (3) regulating RIPK1 phosphorylation directly [27] or indirectly by activating I kappa B kinases (IIKK $\alpha /$ IKK $\beta$ ) [28] or mitogen-activated protein kinase-activated protein kinase 2 (p38MAPK/MK2) [29]. In addition to TAK1- and cIAP-mediated downregulation, more than 70 molecules play a role in the regulation of necroptosis [18], among them Aurora kinase A (AURKA), which interacts directly with RIPK1 and RIPK3 in nontreated cells to reduce unwanted necroptosis [30]. Its downstream target glycogen synthase kinase $3 \beta$ (GSK3 $\beta$ ) regulates the formation of the necrosome and suppresses necroptosis [30]. In the absence of ubiquitylation and/or phosphorylation, RIPK1 transduces cell death signals, and when apoptotic pathways are blocked, necroptosis is activated. Thus, necroptosis is most frequently induced in in vitro experimental systems by utilizing pan caspase inhibitors in combination either with IAP antagonists, termed SMAC mimetics (SM) to block RIPK1 ubiquitination [12], or with TAK1 inhibitors to prevent the phosphorylation of RIPK1 [13]. Necroptotic cell death of macrophages has already been shown following treatment with SM [31] or TAK1 inhibitors [14].

Many clinical trials aim to modify the M1/M2 ratio, but currently, the targeted depletion of a unique macrophage subtype by specific cell death signals is not a therapeutic option. We aimed to identify circumstances in which M2 cells or TAMs are susceptible to cell death signals, but M1 cells remain resistant. We found that M2 macrophages were highly sensitive, while M1 macrophages were unaffected by TAK1 inhibitor-generated necroptosis. The resistant M1 macrophages harness AURKA-mediated inhibition in the downregulation of cell death. In contrary to TAK1 inhibitor, SM treatment results in necroptosis in both macrophage populations, highlighting that at least two different necroptotic pathways operate in macrophages. TAK1 inhibitor-induced necroptosis pushes the ratio of M1/M2 macrophages toward an inflammatory phenotype, which rationalizes the activation of necroptosis for therapeutic intervention in any disease where M1 functions are preferred.

\section{Materials and methods}

\section{Antibodies and reagents}

The following commercial antibodies and reagents were used in this study: Z-VAD, AURKA inhibitor CCT137690, MAPK inhibitors SB203508-p38, U0126-ERK, NFkB inhibitor-TPCA1-IKK were purchased from ApexBio, GSK3ß inhibitor AR-A014418 was from Selleck Chemicals, and SP600125-JNK was from Santa Cruz. TNF alpha was purchased from PeproTech. 5Z-7-oxozeaenol (5Z-7) and RIPK3 inhibitor (GSK'872) were from Sigma-Aldrich. Necrostatin-1 was from Abcam, and TNF-R1:Fc fusion protein was from Adipogen. Lipopolysaccharide (LPS) was from InvivoGen, and Birinapant was from LC Laboratories. The flow cytometry antibodies were purchased from the following companies: CD209-PE (DC-SIGN, BioLegend), CD206-Pe-Cy ${ }^{\mathrm{TM}} 5$ (BD Pharmingen) and CD80-FITC (SONY Biotechnology), CD14-PE (BioLegend), HLA-DR-PercP (BD Pharmingen), PD-1/CD279-PercP (BioLegend), CD163-PE (Biosciences).

\section{Generation of monocyte-derived M1, M2 macrophages and TAM-like cells}

Heparinized leukocyte-enriched buffy coats were obtained from healthy blood donors, and peripheral blood mononuclear cells (PBMCs) were separated from buffy coats by 
Ficoll-Paque Plus (Biosciences) gradient centrifugation. Monocytes were purified from PBMCs by positive selection using immunomagnetic cell separation and anti-CD14conjugated microbeads (Miltenyi Biotec), according to the manufacturer's instructions. After separation on a VarioMACS magnet, $96-99 \%$ of the cells were shown to be $\mathrm{CD} 14^{+}$monocytes.

Isolated monocytes were cultured for 5 days in 6-well tissue culture plates at a density of $2.0 \times 10^{6}$ cells $/ \mathrm{ml}$ in Gibco's serum-free AIM-V medium (Thermo Fischer Scientific) supplemented with $50 \mathrm{ng} / \mathrm{ml}$ M-CSF (PeproTech). In order to acquire the M1 and M2 types, cells were stimulated on the fifth day of differentiation for $24 \mathrm{~h}$ with lipopolysaccharide ( $50 \mathrm{ng} / \mathrm{ml}$ ultrapure LPS, InvivoGen), IFN $\gamma$ (20 ng/ml, PeproTech) to M1 and IL-4 (20 ng/ml, PeproTech), IL-10 (20 ng/ $\mathrm{ml}$, PeproTech) and TGFß (20 ng/ml, PeproTech) to M2 phenotype. For the differentiation of TAM-like cells, isolated monocytes were cultured for 5 days in 6-well tissue culture plates at a density of $2.0 \times 10^{6}$ cells $/ \mathrm{ml}$ in Thp- 1 supernatant supplemented with IL-4 (20 ng/ml), IL-10 $(20 \mathrm{ng} / \mathrm{ml})$ and TGFß $(20 \mathrm{ng} / \mathrm{ml})$. On the fifth day, TAM-like cells were treated again with Thp- 1 supernatant for $24 \mathrm{~h}$.

\section{Production of THP-1 supernatant}

To generate THP- 1 supernatant, cells were cultured at a density of $2 \times 10^{5}$ cells $/ \mathrm{ml}$ in Gibco's serum-free AIM-V medium (Thermo Fischer Scientific) for 2 days and the supernatant was collected at $1500 \mathrm{rpm}$ for $5 \mathrm{~min}$.

\section{Measurement of cytokine concentration}

The supernatants of M1 and M2 macrophages were harvested on the sixth day of differentiation, and the concentrations of IL-12 and IL-10 cytokines were measured using OptEIA kits (BD Biosciences) following the manufacturer's instructions.

\section{Flow cytometry}

Cell death was induced by TAK1 inhibitor (5Z-7-oxozeaenol $1 \mu \mathrm{M}$ ), IAP antagonist (Birinapant $0.5 \mu \mathrm{M}$ ) LPS $(100 \mathrm{ng} / \mathrm{ml})$, TNF alpha $(60 \mathrm{ng} / \mathrm{ml})$, caspase inhibitor (Z-VAD $50 \mu \mathrm{M}$ ), RIP1K inhibitor, Necrostatin-1 $38.5 \mu \mathrm{M}$ ), RIPK3 inhibitor (GSK'872 7.5 $\mu \mathrm{M})$, AURKA inhibitor (CCT137690 $1.25 \mu \mathrm{M}$ ), GSK3 $\beta$ inhibitor (AR-A014418 $10 \mu \mathrm{M}$ ) and MAPK (SP600125-JNK $1 \mu \mathrm{M}$; SB203580-p38 $1 \mu \mathrm{M}$; U0126-Erk $1 \mu \mathrm{M}$ ) and NFKB inhibitors (TPCA1IKK $1 \mu \mathrm{M}$ ) on M1, M2, TAM and M1-M2 co-cultured macrophages.

Total cell death was quantified based on the loss of membrane integrity and the uptake of propidium iodide (PI, Sigma-Aldrich). Cells were stained with PI $(10 \mu \mathrm{g} / \mathrm{ml})$ before analysis by flow cytometry. Cell death was measured by flow cytometry using FACS Calibur (BD Biosciences), and data were analyzed by FlowJo software (Tree Star, Ashland, OR, USA).

\section{Western blotting}

Protein extraction was performed by lysing the cells in $2 \times$ Laemmli sample buffer. Proteins were separated by SDS gel electrophoresis using $10 \%$ polyacrylamide gels and transferred onto nitrocellulose membranes ER (Bio-Rad Laboratories). Nonspecific binding was blocked by TBS-Tween with 5\% nonfat dry milk. Transfer membranes were immunoblotted with the indicated antibodies: RIPK1 (BD Biosciences), RIPK3 (Cell Signaling), MLKL (Sigma-Aldrich), pMLKL (Cell Signaling), TAK1 (Cell Signaling), GSK3ß (Cell Signaling), Aurora A (Cell Signaling), p38 (Thermo Fischer Scientific), pErk (Thermo Fischer Scientific), pJNK (Thermo Fischer Scientific), pIкß (R\&D Systems) and $\beta$-actin (Sigma-Aldrich) all diluted 1:1000. Anti-rabbit (GE Healthcare), anti-mouse (GE Healthcare) or anti-rat (SigmaAldrich) antibodies conjugated to horseradish peroxidase were used as the secondary antibodies.

\section{Co-cultures of M1-M2 cells}

To test the functional importance of differences in cell death intensity between M1 and M2 cells, a macrophage co-culture was created.

An equal number of M1 and M2 macrophages, $4 \times 10^{5}$ cells $/ 0.5 \mathrm{ml}$, were co-cultured for $4 \mathrm{~h}$ in 24-well tissue culture plates. Mixture of M1 and M2 cells was treated with necroptotic stimuli. The percentage of surviving macrophages was labeled with anti-CD209-PE and anti-CD80FITC antibodies in $24 \mathrm{~h}$.

To distinguish between M1 and M2 cell death, M2 macrophages were stained using CellTracker ${ }^{\mathrm{TM}}$ Green CMFDA Dye (Thermo Fischer Scientific). M2 cells were loaded with $10 \mathrm{ng} / \mathrm{ml}$ CellTracker ${ }^{\mathrm{TM}}$ Green CMFDA Dye at $37{ }^{\circ} \mathrm{C}$ for $30 \mathrm{~min}$. After intense washing, $4 \times 10^{5}$ cells in $0.5 \mathrm{ml}$ volume were co-cultured with unlabeled M1, in the same concentration in 24-well tissue culture plates. M1 and M2 co-cultures were treated with necroptotic stimuli, and the cell death of the different populations was determined after $24 \mathrm{~h}$ by PI staining.

\section{Statistical analysis}

Two-way ANOVA or one-way ANOVA followed by Sidak's multiple-comparison test was used for multiple comparisons. Results are expressed as mean \pm SD. In the case of IL10 and IL-12 production, significance was calculated by Student's 
$t$ test. The results are expressed as mean $+\mathrm{SD}$. All analyses were performed by using GraphPad Prism software, version 6.0. Differences were considered to be statistically significant at $P<0.05$. Significance is indicated by $* P<0.05$; $* * P<0.01 ; * * * P<0.005$.

\section{Results}

\section{M2 macrophages, but not M1 cells are sensitive to TAK1 inhibitor-induced necroptosis}

Controlling the balance of pro-inflammatory versus antiinflammatory macrophages may provide immediate therapeutic benefit. As a new concept for therapeutic intervention, we compared the sensitivity of human M1 and M2 macrophages to various cell death stimuli. For this, blood-derived CD14+ monocytes were separated and differentiated, in accordance with previous studies, in the presence of M-CSF for five days to M0 macrophages and then polarized toward the $\mathrm{M} 1$ and $\mathrm{M} 2$ cells by stimulation for $24 \mathrm{~h}$ with LPS/IFN $\gamma$ or IL-4/TGF $\beta$, respectively [32]. To confirm the polarization of subtypes, we analyzed cell surface marker expression on the differentiated macrophages. We detected the induction of CD80 on M1 cells, and higher expression level of prototypical M2 markers CD206 and CD209 on M2 cells (Fig. 1a). We also checked the functionality of the two cell populations by measuring the production of M1- and M2-related cytokines. According to widely used protocols, M1 cells released significantly higher amounts of IL-12 than the M2 population, but IL-10 production was more relevant in M2 macrophages (Fig. 1b, c) [33].

To check the susceptibility to cell death stimuli of polarized M1 and M2 macrophages, we treated these cell types with various apoptotic and necroptotic activators. We used LPS, TNF, SMAC mimetic (birinapant), TAK1 inhibitor

\section{A}
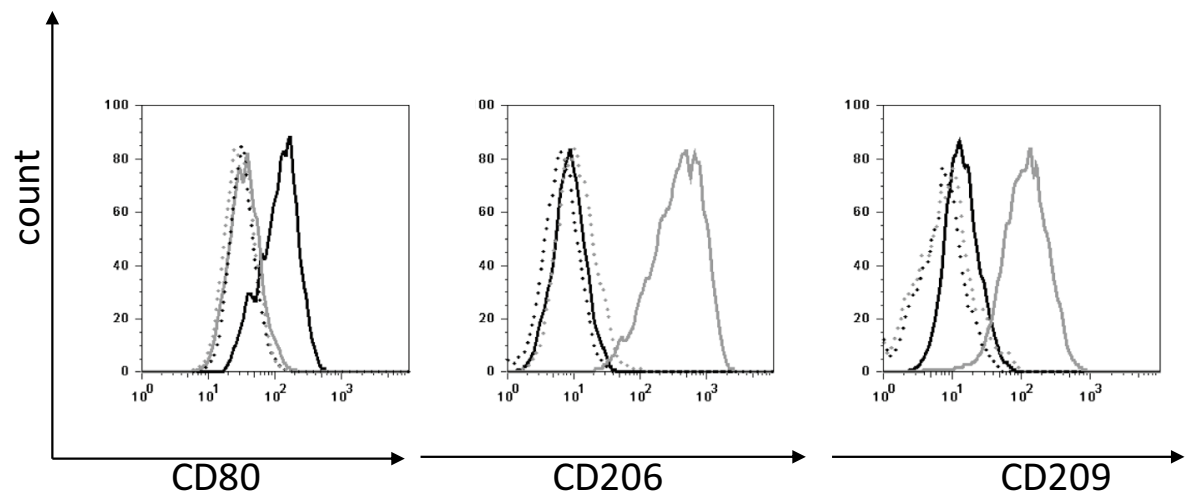

$\square \mathrm{M} 1$ M2

B

$\mathrm{IL}-12$

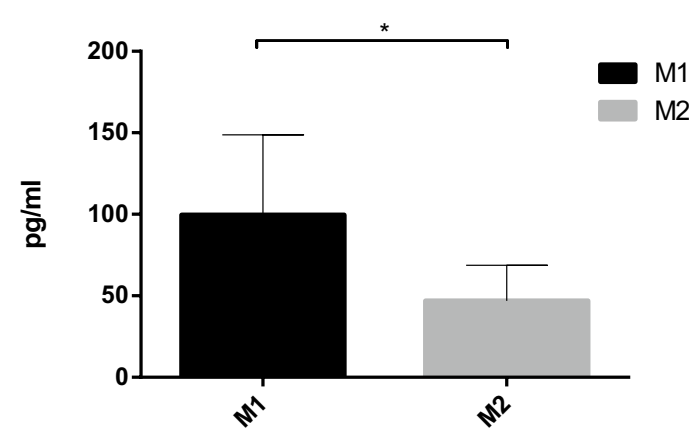

Fig. 1 In vitro differentiation of M1 and M2 macrophages. a Human monocyte-derived macrophages were differentiated to M1 and M2 phenotype in the presence of LPS $(50 \mathrm{ng} / \mathrm{ml})$ and IFN $\gamma(20 \mathrm{ng} / \mathrm{ml})$ or IL-4 (20 ng/ml), IL-10 (20 ng/ml) and TGFß (20 ng/ml), respectively. The cell surface expressions of CD80, CD206 and CD209 were

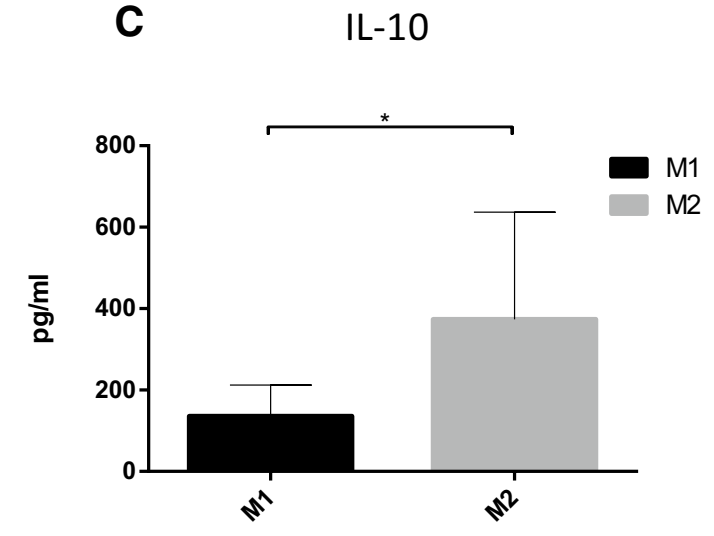

measured on the two cell types by flow cytometry. Representative images of five independent experiments are shown. b, c The IL-12 and IL-10 production was measured by ELISA. The figure shows the average of three independent experiments 
A

B

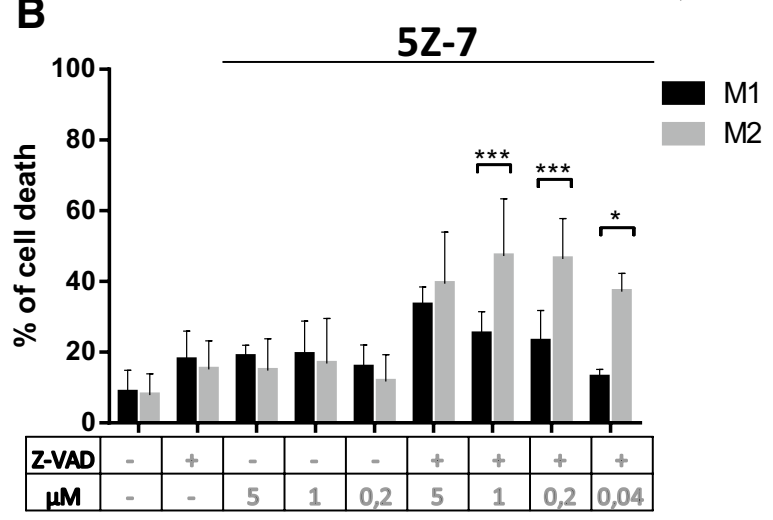

D

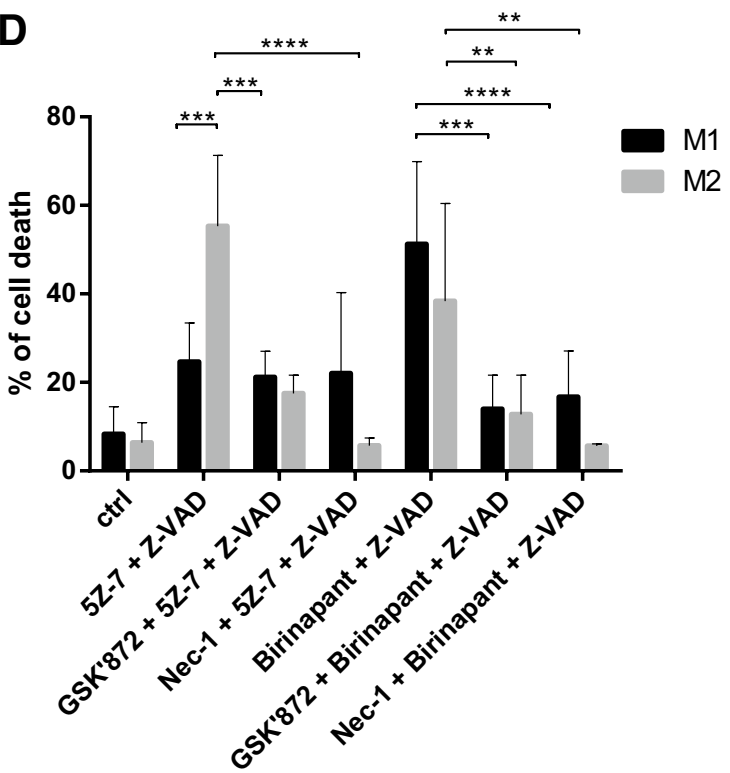

Fig. 2 TAK1 inhibitor induces necroptosis on M2, but not on M1 cells. a The in vitro differentiated human M1 and M2 cells were stimulated with $100 \mathrm{ng} / \mathrm{ml}$ LPS, $60 \mathrm{ng} / \mathrm{ml} \mathrm{TNF}, 0.5 \mu \mathrm{M}$ birinapant and $1 \mu \mathrm{M}$ 5Z-7-oxozeaenol with and without $50 \mu \mathrm{M}$ Z-VAD. b, c Cells were stimulated with the indicated dose of or 5Z-7-oxozeaenol or birinapant in the presence or absence of $50 \mu \mathrm{M}$ Z-VAD. d Cells were pretreated with $7.5 \mu \mathrm{M}$ GSK'872 RIPK3 inhibitor and

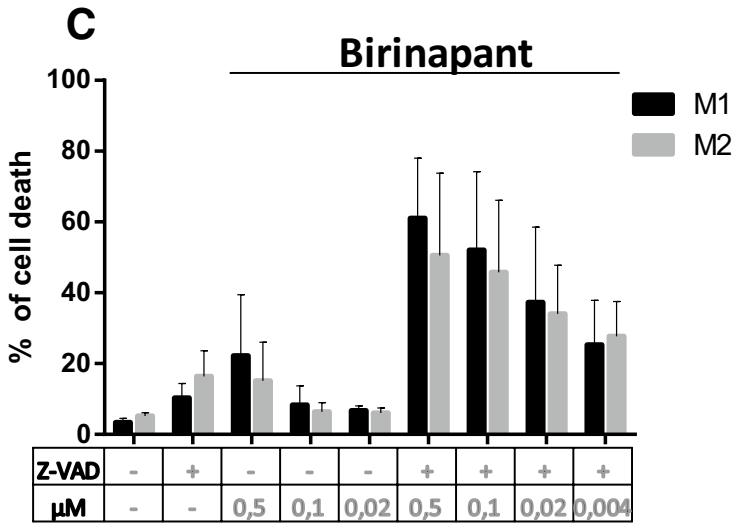

$\mathbf{E}$

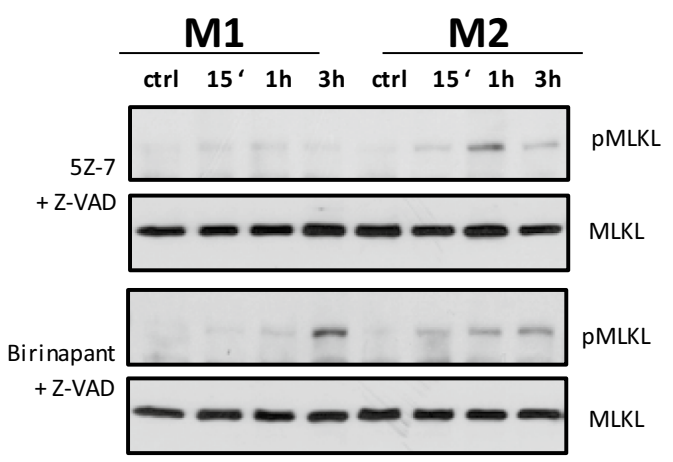

$38.5 \mu \mathrm{M}$ Necrostatin- 1 for $1 \mathrm{~h}$, after which $0.5 \mu \mathrm{M}$ birinapant or $1 \mu \mathrm{M}$ 5Z-7-oxozeaenol together with $50 \mu \mathrm{M} \mathrm{Z}$-VAD was added. After $24 \mathrm{~h}$, cell death was determined by PI staining. Figures show the mean plus SD of at least three independent experiments. e MLKL phosphorylation (S358) was detected by WB following $0.5 \mu \mathrm{M}$ birinapant or $1 \mu \mathrm{M}$ 5Z-7-oxozeaenol treatment for the indicated times. A representative image of three independent experiments 
A

M1-M2

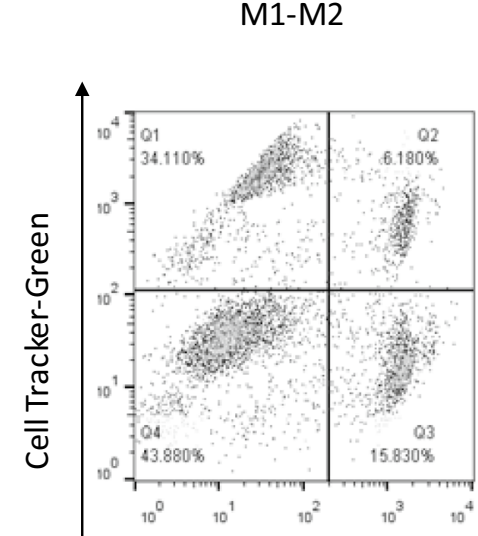

$\mathrm{M} 1-\mathrm{M} 2$

5Z-7+Z-VAD

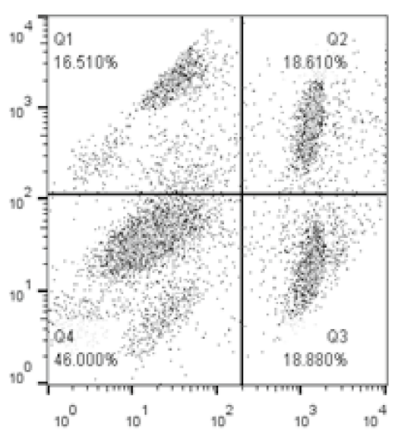

M1-M2

Birinapant+Z-VAD
$\mathrm{M} 1$

$\mathrm{M} 2$

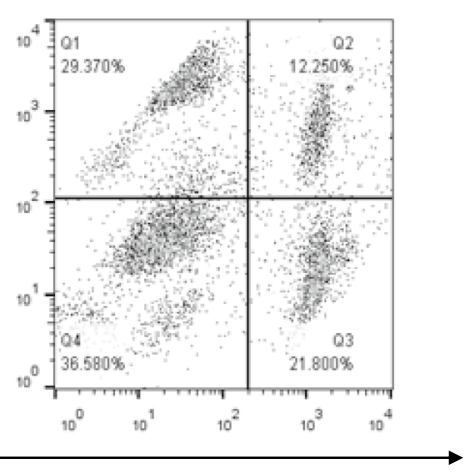

Propidium lodide
B

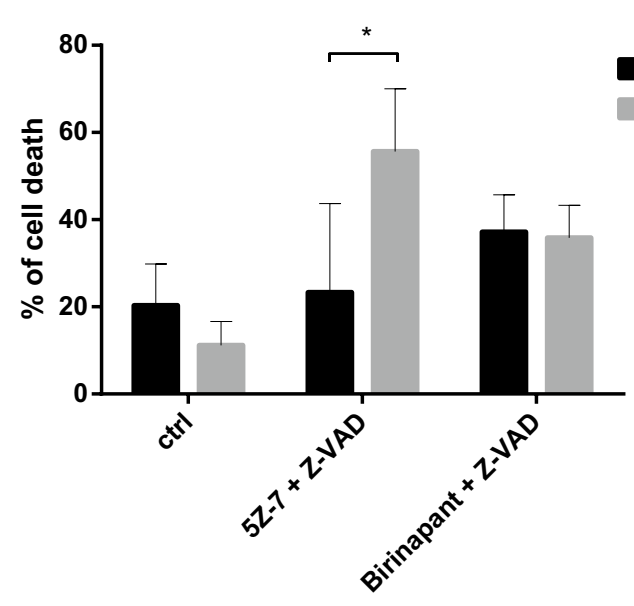

D
M1-M2

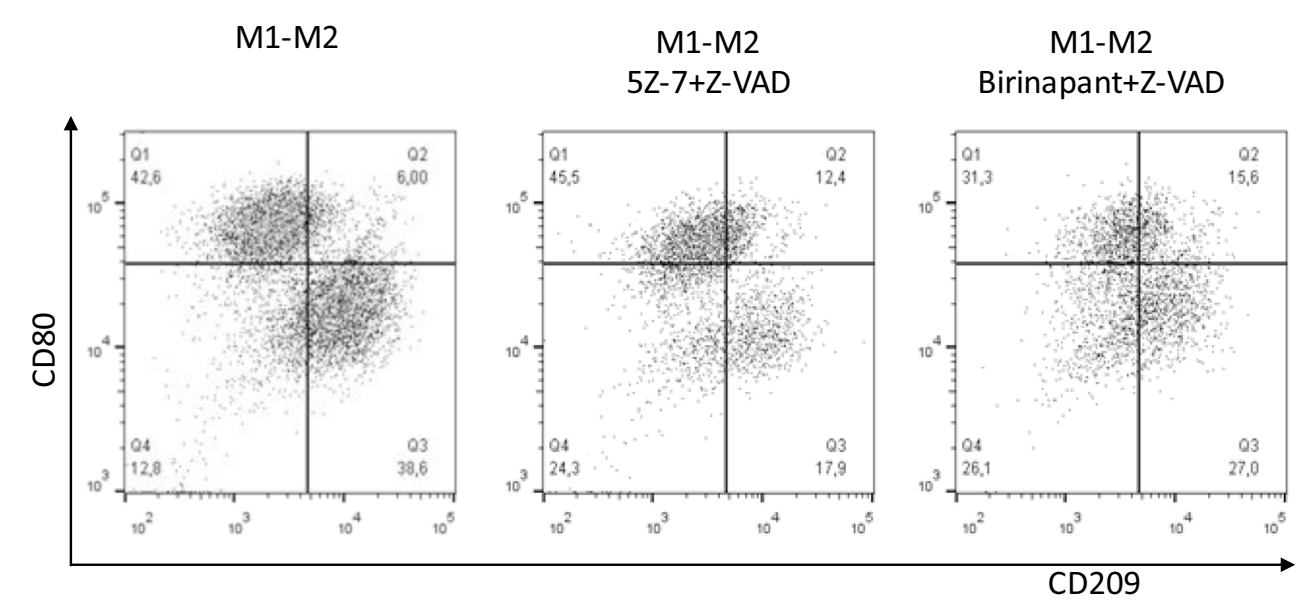

C

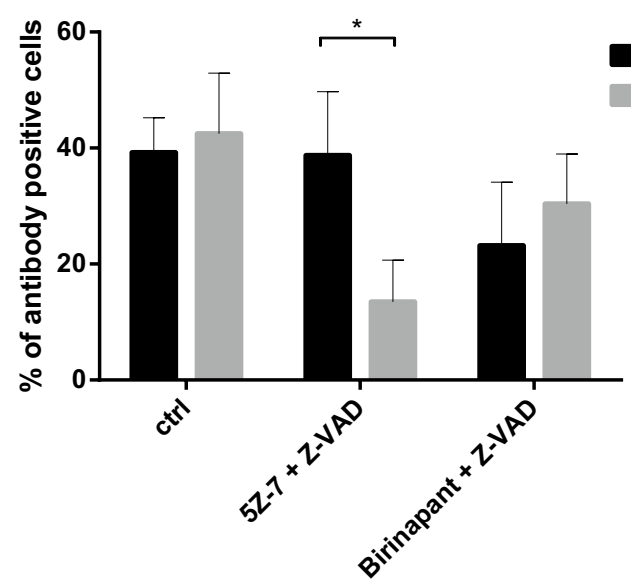

CD80

CD209
(5Z-7-oxozeaenol; 5Z-7) and the combinations of these treatments as apoptotic triggers. In the presence of a caspase inhibitor (Z-VAD), all these stimulants are well-known activators of necroptosis in macrophages [14, 31]. All the investigated stimuli induced cell death at the same level in both cell populations, but TAK1 inhibitor-induced necroptosis was significantly higher in M2 cells (Fig. 2a).
To confirm this result, we studied the dose dependence of birinapant- and 5Z-7-mediated cell death. 5Z-7-induced cell death was more intense in M2 cells than in M1 macrophages under caspase-compromised conditions at all investigated doses (Fig. 2b). Under the same experimental settings, birinapant treatment did not result in higher cell death intensity in M2 than in M1 macrophages at any dose. 
4Fig. 3 TAK1 inhibitor induces necroptosis on M2, but not on M1 cells in the co-culture of macrophage populations. a, b M2 cells were loaded with $10 \mathrm{ng} / \mathrm{ml}$ CellTrackerTM Green CMFDA Dye for $30 \mathrm{~min}$. Green labeled M2 cells and M1 cells were mixed and the cells were treated with $0.5 \mu \mathrm{M}$ birinapant or $1 \mu \mathrm{M} 5 \mathrm{Z}-7$-oxozeaenol with $50 \mu \mathrm{M}$ Z-VAD. a The degree of total cell death was quantified based on the uptake of PI. b A representative image of five independent experiments is documented. Percentage of cell death was calculated in the CellTracker positive and CellTracker negative populations. Figures show the mean plus SD of at least five independent experiments. c, d M1 and M2 cells were co-cultured and the cells were treated with $0.5 \mu \mathrm{M}$ birinapant or $1 \mu \mathrm{M} 5 \mathrm{Z}-7$-oxozeaenol in the presence of $50 \mu \mathrm{M}$ Z-VAD for $24 \mathrm{~h}$. c The cell surface expression of CD80 and CD209 were measured by flow cytometry before and after $24 \mathrm{~h}$ the indicated treatments. The living cells were gated and the percentage of CD80 positive CD209 negative (CD80) and CD209-positive CD80 negative (CD209) cells were determined. Figure shows the mean plus SD of at least five independent experiments. $\mathbf{d}$ The cell surface expression of CD80 and CD209 were measured by flow cytometry before or $24 \mathrm{~h}$ after the indicated treatments. A representative image of five independent experiments is shown

Birinapant-induced cell death was even slightly, but nonsignificantly, more intense in M1 cells (Fig. 2c). We checked whether the detected cell death in caspase-inhibited conditions is due to necroptosis. For this, we pretreated the polarized macrophages with a specific RIPK1 inhibitor Necrostatin-1 (Nec-1) and RIPK3 inhibitor (GSK'872). We observed that Nec-1 and GSK'872 blocked birinapant/Z-VAD (BZ)induced cell death equally in the two cell types. In the case of M2 cells, Nec-1 and GSK'872 also inhibited the 5Z-7/ZVAD-induced cytotoxicity (Fig. 2d). We also analyzed the phosphorylation of MLKL following BZ and 5Z-7/Z-VAD activation as a characteristic marker of necroptosis. We detected phospho-MLKL upon BZ activation in both M1 and M2 cells, but its phosphorylation occurred only in M2 macrophages following 5Z-7/Z-VAD stimulation (Fig. 2e). TNF-R1: Fc fusion protein only partially, but not significantly inhibited 5Z-7/Z-VAD or BZ -induced necroptosis, indicating that other mechanisms than autocrine TNF production may also play a role in 5Z-7/Z-VAD- or BZ-induced necroptosis in human macrophages (data not shown).

Altogether, M2 macrophages are sensitive, but M1 cells are intrinsically resistant to 5Z-7/Z-VAD-induced necroptosis, whereas all other examined stimuli caused the same intense cell death in the two differently polarized macrophage populations.

\section{Co-culturing M1 and M2 cells does not sensitize M1 cells to TAK1 inhibitor-induced necroptosis}

The two different macrophage phenotypes are present simultaneously at the site of chronic inflammation or in the tumor microenvironment. We tested the ability of the two cell types to regulate each other's sensitivity to necroptosis by co-culturing M1 and M2 cells. We loaded M2 macrophages with CellTracker ${ }^{\mathrm{TM}}$ Green CMFDA Dye and co-cultured cells were treated with BZ or 5Z-7/Z-VAD for $24 \mathrm{~h}$. We determined the intensity of cell death in both CellTrackerpositive and -negative populations. Consistent with the results observed with the separately treated cell types, M2 cells were sensitive, but M1 cells remained resistant to 5Z-7/Z-VAD-induced necroptosis. In contrast, BZ treatment effectively killed both macrophage populations in the coculture (Fig. 3a, b). We confirmed this result by measuring the cell surface markers of the surviving cell populations before and after the induction of cell death. 5Z-7/Z-VAD treatment reduced the amount of CD209 positive cells and consequently pushed the balance of M1/M2 cells toward M1 excess, while BZ treatment had no significant effect on the M1/M2 ratio (Fig. 3c, d). Overall, the treatment of co-cultured M1 and M2 macrophages with TAK1 inhibitor shifted the balance of surviving cells toward M1 dominance. Based on these results, we can conclude that the difference in the sensitivity of the two macrophage subtypes to necroptosis does not depend on M2-derived cytotoxic or M1-derived survival factors, but is regulated by the intrinsic properties of the two cell subtypes.

\section{The inhibition of the downstream components of TAK1 signaling induces necroptosis in M2 cells}

TAK1 regulates the activation of mitogen-activated protein kinases (MAPKs) and nuclear factor kappa B (NFkB) signaling. We attempted to find which downstream component of TAK1 signaling could be responsible for TAK1 inhibitorinduced necroptosis. For this purpose, molecules in TAK1regulated pathways were inhibited one by SP600125 (JNK inhibitor), SB203508 (p38MAPK inhibitor), U0126 (ERK inhibitor) and TPCA1 (IKK inhibitor). Under caspase-compromised conditions, all these inhibitors induced cell death in M2 macrophages. When we used suboptimal doses of these inhibitors, we detected more intense cell death in M2 than in M1 cells. All observed differences were significant, except for p38 kinase inhibitors (Fig. 4a-d). Caspase activity protected both macrophage subtypes from MAPK or IKK inhibition-induced necroptosis. Combinations of these inhibitors also induced more intense cell death in M2 than in M1 macrophages (Fig. 4e). Phorbol 12-myristate 13-acetate (PMA) treatments resulted in comparable intense phosphorylation of MAPKs and IкB in M1 and M2 cells, indicating that the observed differences in cell death appear to be due to alterations in the necroptotic pathway, and not due to the availability of MAPK signaling (Figure Supplementary S1). According to our observations, we concluded that the absence of any survival signals results in the necroptosis of M2 cells under caspase-compromised conditions, but presumably M1 macrophages utilize additional survival signals to block TAK1 inhibition-mediated necroptosis. 
A

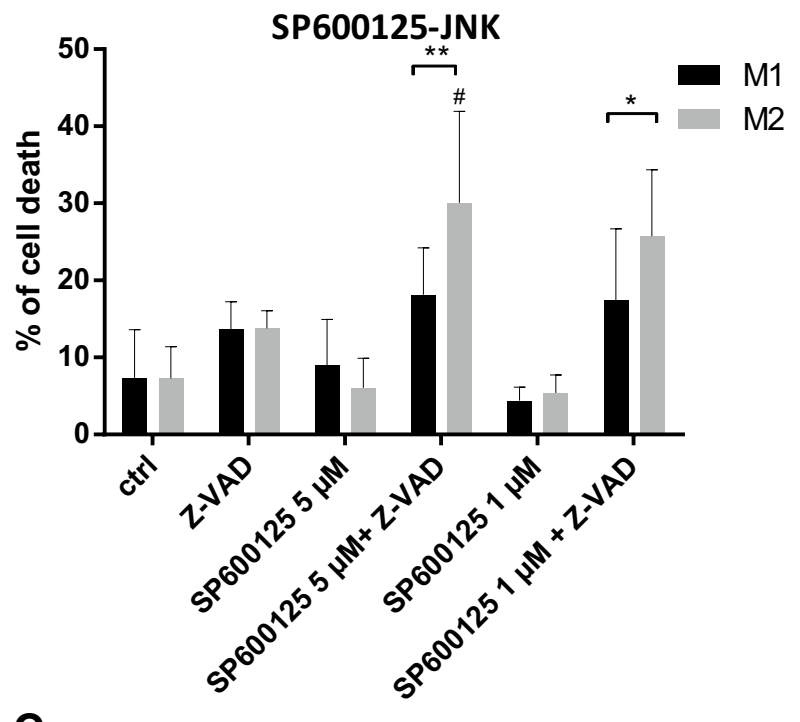

C

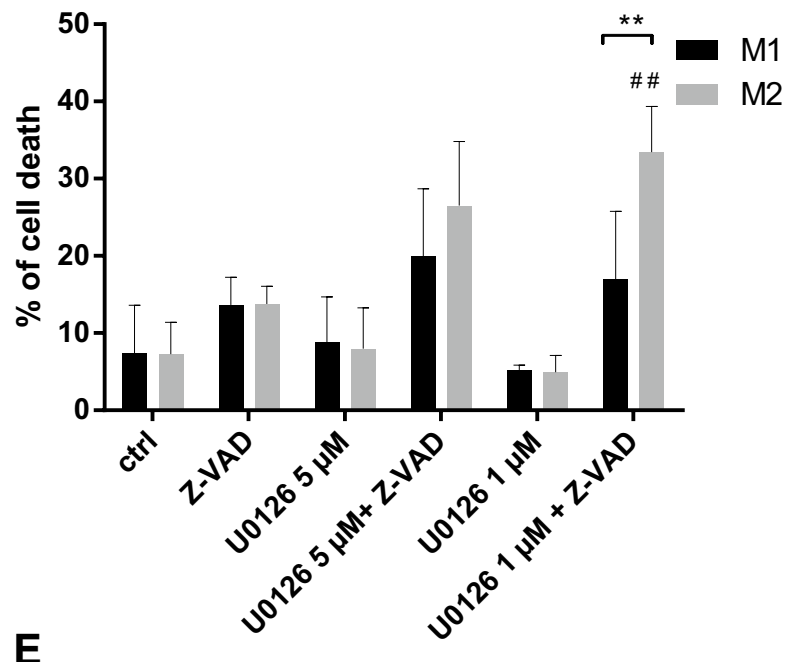

B
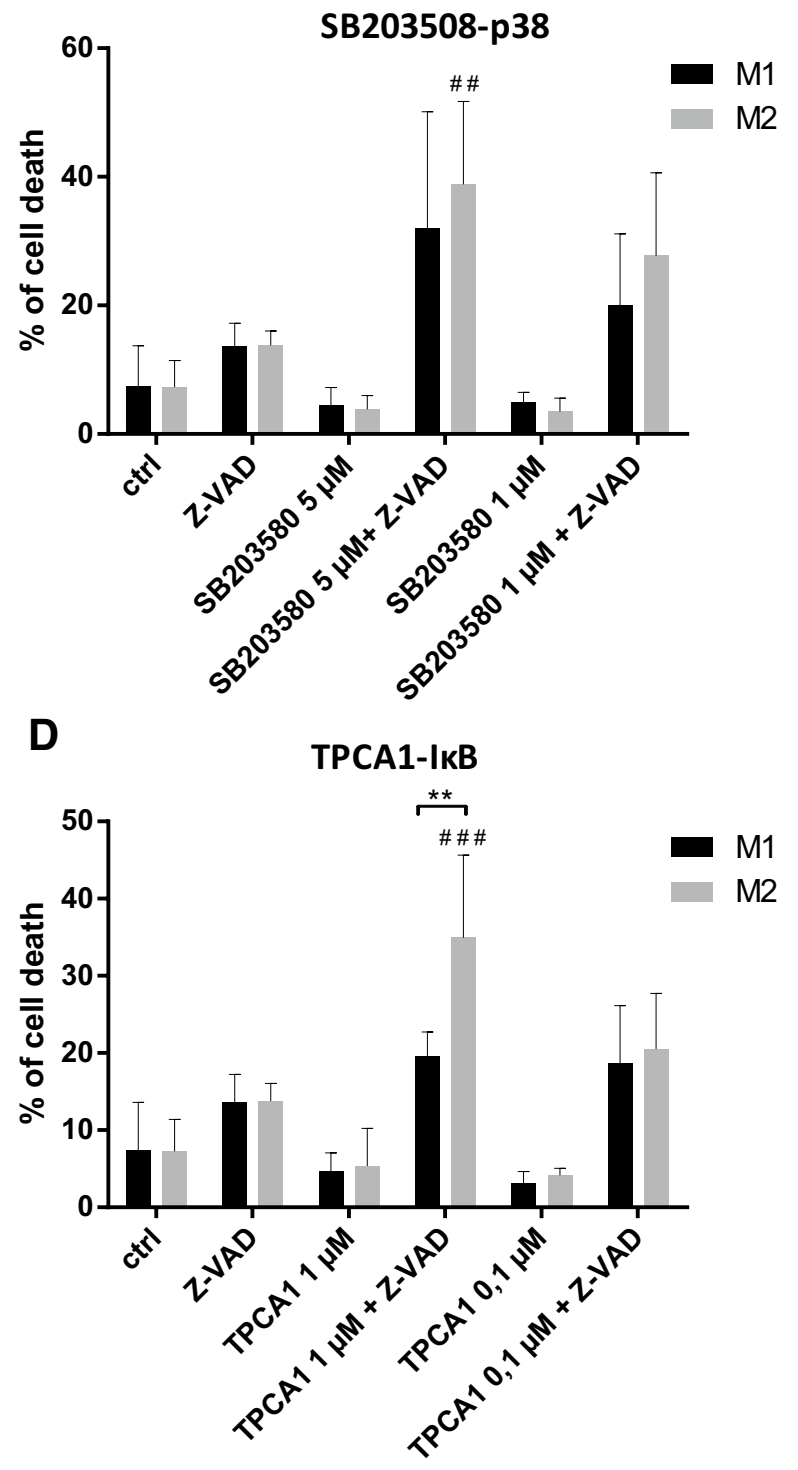

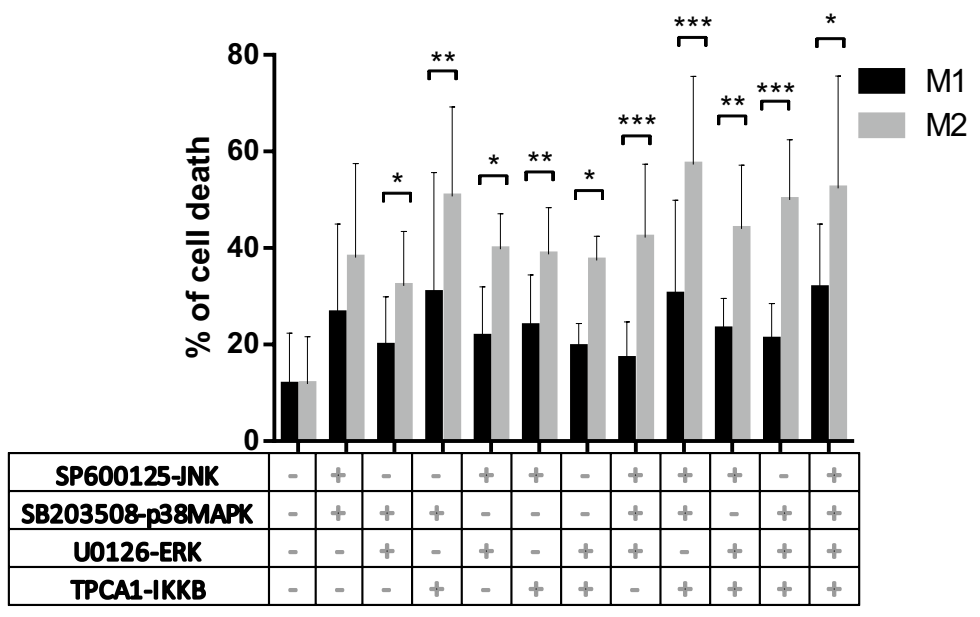


4Fig. 4 p38MAPK, JNK, ERK and IKK inhibitors induce cell death in M2 macrophages. The in vitro differentiated human M1 and M2 cells were stimulated in the presence or absence of $50 \mu \mathrm{M} \mathrm{Z-VAD}$ for $24 \mathrm{~h}$ with the indicated dose of a SP600125 (JNK inhibitor), b SB203508 (p38MAPK inhibitor), c U0126 (ERK inhibitor) and d TPCA1 (IKK inhibitor) or $\mathbf{e}$ with the combinations of these inhibitors. The degree of total cell death was quantified based on the uptake of PI. Figures show the mean plus SD of at least five independent experiments. \# represents significant differences to the Z-VAD treated sample

\section{Inhibitors of Aurora kinase A increased the sensitivity of M1 cells to TAK1 inhibitor-induced necroptosis}

To explore the molecular background behind the different sensitivities of M1 and M2 cells to necroptosis, we checked the protein expression of necrosome components in M1 and M2 cells. However, we could not detect considerable differences in RIPK1, RIPK3 or MLKL expression (Fig. 5a). Because our results suggested the existence of an extra survival signal in M1 cells, we focused on the inhibitors of necroptosis. AURKA has been recently identified as an inhibitor of necroptosis, which binds to RIPK3 and/or RIPK1 in resting cells and blocks the assembly of the necrosome [30]. GSK3 $\beta$ kinase was identified as the downstream mediator of AURKA in the downregulation of necroptosis. AURKA inhibitor (CCT137690) and GSK3 $\beta$ inhibitor (AR-A014418) have been shown to induce necroptosis in the PDAC cell line [30]. Our results show that treatment with CCT or AR had only minimal effect on macrophage survival under caspase-compromised conditions. Co-administration of BZ with these inhibitors did not significantly change the effect of BZ-induced necroptosis on either M1 or M2 cells (Fig. 5d, e). Importantly, cell death of M1 cells was significantly higher upon 5Z-7/Z-VAD stimulus in the presence of either CCT or AR (Fig. 5b, c). To check the modality of cell death detected in the presence of CCT and AR, we pretreated the polarized macrophages with Nec- 1 or GSK' 872 . We observed that Nec-1 and GSK'872 completely blocked the BZ-CCT- or BZ-AR-induced cell death (Fig. 5d, e, Figure Supplementary S2) and Nec-1 and GSK'872 also completely inhibited the 5Z-7/Z-VAD-CCT- or 5Z-7/ZVAD-AR-induced cell death in M1 and M2 cells (Fig. 5b, c, Figure Supplementary S2).

Because CCT or AR had no effect on 5Z-7/Z-VADinduced necroptosis on M2 cells, AURKA or GSK3 $\beta$ inhibitors rendered the two macrophage populations equally sensitive to TAK1 inhibitor-induced necroptosis. We checked the protein expression of AURKA and GSK $3 \beta$ in M 1 and M2 cells, but could not detect any differences. These results indicate that the AURKA- or GSK3 $\beta$-mediated survival pathway, but not the expression level of these kinases, may differ between M1 and M2 cells (Fig. 5a).

\section{TAM-like macrophages are sensitive to TAK1-inhibitor-induced necroptosis}

Based on our observations (Fig. 2b), monocyte-derived M2 cells are more prone to TAK1 inhibitor-induced necroptosis than M1 cells. Because the M2-like TAMs show similar functional properties to M2 macrophages, TAMs were in vitro differentiated and the cell death intensities of these TAM-like cells were compared to M1 cells (Fig. 6a-c). Isolated monocytes were plated in medium complemented with M-CSF and IL-10, IL-4 and TGF $\beta$ and the supernatant of THP-1 cells. In vitro differentiated TAM-like cells were characterized by flow cytometry. In good accordance with published data [34-36], these cells were CD206 and CD163 positive, but expressed low amounts of CD14 (Fig. 6b, c), while the appearance of MCHII [37] and PD-1 [38] was more intense on the surface of TAM-like cells compared to M1 and M2 macrophages (Fig. 6c). The differentiated TAMlike cells were treated with $\mathrm{BZ}$ and $5 \mathrm{Z}-7 / \mathrm{Z}-\mathrm{VAD}$ to induce necroptosis. We found that TAM-like cells were as sensitive to BZ-induced necroptosis as M1 cells, but significantly more susceptible to 5Z-7/Z-VAD treatments than M1 macrophages (Fig. 6d). Sensitivity of TAM-like macrophages to TAK1-inhibitor-induced necroptosis promises to be an effective therapeutic strategy to eliminate immunosuppressive macrophages, while preserving the inflammatory M1 cells in the tumor microenvironment.

\section{Discussion}

Due to the heterogenicity of macrophages, dramatic functional differences have been observed depending on their polarization. The two extremes in the spectrum are M1 macrophages, which are responsible for the initiation of inflammation, and alternatively activated M2 macrophages with anti-inflammatory properties. Targeted modulation of M1/M2 transition may offer promising strategies to cure various life-threatening diseases. Accordingly, ongoing clinical trials aim to modulate M1/M2 balance in cancer $[5,6]$, atherosclerosis [2], sclerosis multiplex [39] or endometriosis [40]. Currently, the therapeutic approaches to alter the ratio of macrophage subsets are bipartite, on the one hand directing the differentiation of these cells, and on the other hand, altering the function of the differentiated cells [6]. In addition, targeted depletion of each macrophage type also offers a therapeutic option to regulate the M1/M2 ratio. This strategy can be relevant, especially in TME, where cell death induction is certainly the main therapeutic intervention [6]. Necroptotic stimuli, among them SMs [41] and TAK1 inhibitors [42], have been tested in various ongoing clinical trials to eliminate apoptosisresistant tumor cells. However, necroptosis induction in 
A
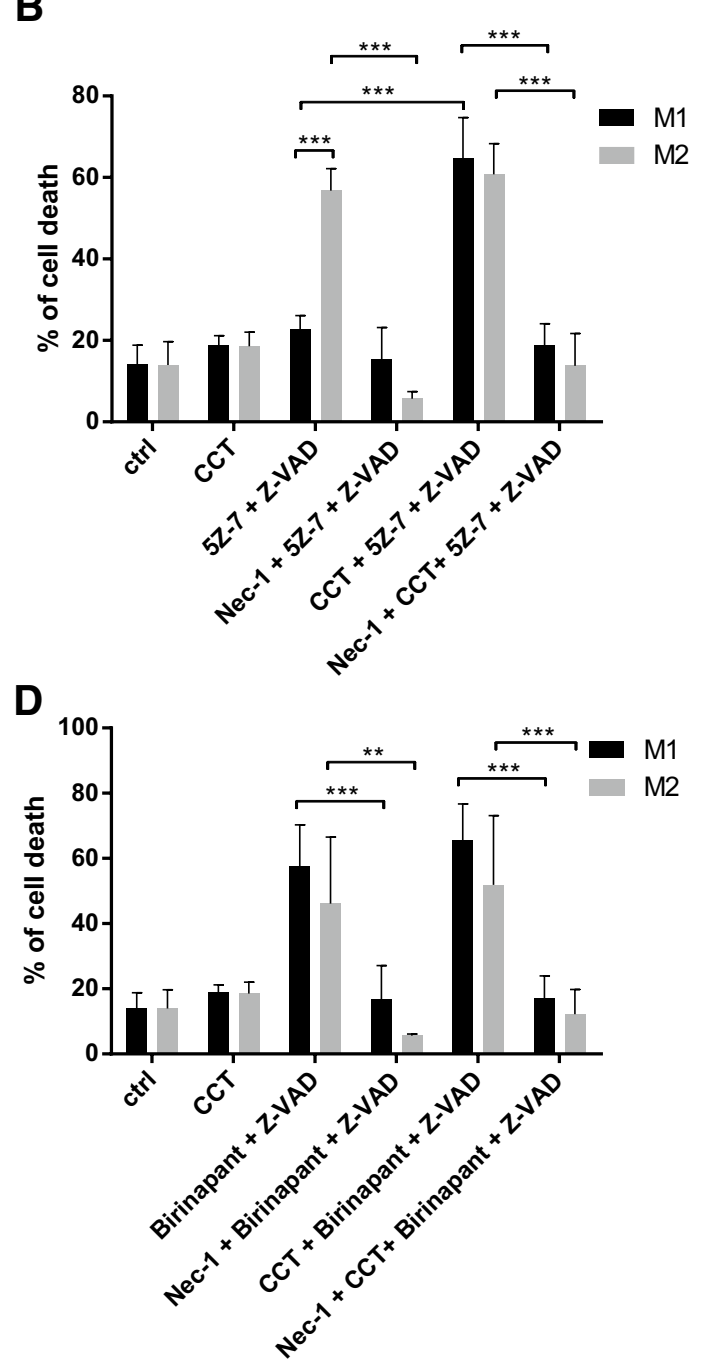

C

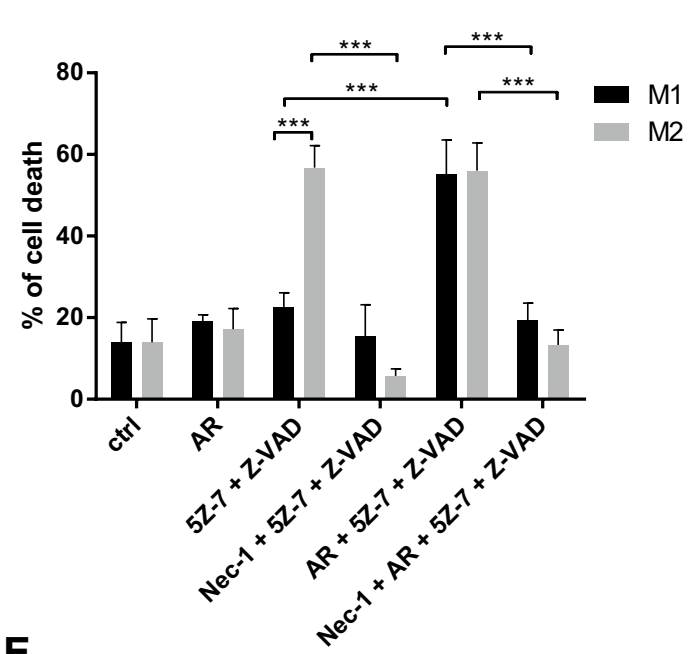

E

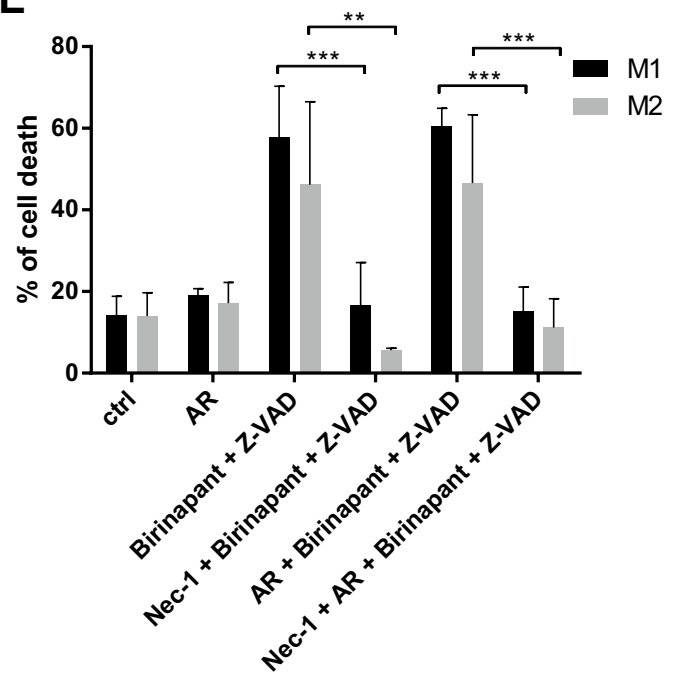


4Fig. 5 Aurora kinase A inhibitor restores the TAK1 inhibitor-induced cell death in M1 macrophages. a The expressions of the indicated molecules were visualized by western blotting of total cell lysates in the in vitro differentiated human M1 and M2 cells. A representative image of three independent experiments is documented. b, c Macrophages were pre-treated with $1.25 \mu \mathrm{M}$ CCT137690 (AURKA inhibitor) and $10 \mu \mathrm{M}$ AR-A014418 (GSK3 $\beta$ ) inhibitor, $38.5 \mu \mathrm{M}$ Necrostatin-1 for $1 \mathrm{~h}$ followed by activation with $1 \mu \mathrm{M}$ 5Z-7-oxozeaenol together with $50 \mu \mathrm{M} \mathrm{Z-VAD.} \mathrm{d,} \mathrm{e} \mathrm{Macrophages} \mathrm{were} \mathrm{pre-treated} \mathrm{with}$ $1.25 \mu \mathrm{M}$ CCT137690 (AURKA inhibitor) and $10 \mu \mathrm{M}$ AR-A014418 (GSK3 $\beta$ ) inhibitor, $38.5 \mu \mathrm{M}$ Necrostatin- 1 for $1 \mathrm{~h}$ followed by activation with $0.5 \mu \mathrm{M}$ birinapant together with $50 \mu \mathrm{M}$ Z-VAD. b-e After $24 \mathrm{~h}$ the extent of cell death was determined by measuring the PI staining. The figure shows the mean plus SD of at least five independent experiment

the TME is a double-edged sword, because necroptosis in the TME can also result in immunosuppression, and necroptotic cell death of endothelial cells promotes tumor cell extravasation and metastasis [18]. Consequently, the effect of any necroptosis inducers should be checked also on the TME in addition to its tumor-killing capacity. The effect of SM and TAK1 inhibitors on the cellular components of tumor-associated stroma is not clearly investigated.

Macrophages are relatively resistant to apoptosis, but are highly sensitive to necroptosis [43]. SMAC mimetics have been reported to trigger cell death in macrophages, especially under caspase-compromised conditions [31], and TAK1 inhibitors are also well known to induce necroptosis in macrophages [14].

We attempted to compare the sensitivity of M1 and M2 macrophages to various cell death stimuli. The two macrophage populations were equally sensitive to most of the investigated apoptotic or necroptotic inductions, but we observed that monocyte-derived $\mathrm{M} 2$ cells are more prone to TAK1 inhibitor-induced necroptosis than M1 cells. Because the M2-like TAMs generally show similar functional properties as M2 macrophages, the question arose as to whether these two anti-inflammatory populations use similar cell death pathways. We generated TAM-like cells in vitro by using the traditional M2 differentiation protocol and THP-1 conditioned media. TAM-like macrophages, as well as M2 cells, were sensitive to TAK1 inhibitor-induced necroptotic stimuli. The difference in the sensitivity of M1 and M2 macrophages to TAK1 inhibitor-induced necroptosis was still observed when the two cell populations were co-cultured, which results in exclusion the possibility that the effect is due to an autocrine cytotoxic factor exclusively produced by M2 cells. Our findings suggest that TAK1 inhibitors are more promising candidates for tumor therapy than SM due to the intense killing of anti-inflammatory macrophages.
However, further investigations are needed to check the effect of the two necroptotic treatments on other suppressive cell types in the TME, and in vivo studies should also be performed to investigate the recruitment of various cells following treatments with both TAK1 inhibitor and SM. The use of TAK1 inhibitor instead of SM is rationalized not only by the susceptibility of M2- and TAM-like macrophages to TAK1 inhibitor-induced necroptosis but also by the fact that TAK1-mediated events also have been demonstrated in all growth factor signaling, Treg cell development, epithelial-mesenchymal transition, angiogenesis and in resistance to conventional chemotherapy [42].

Investigation of the intrinsic signaling pathways of the two cell types indicates that any perturbation in the survival signals resulted in necroptosis in M2 cells, but M1 cells were relatively unaffected. The higher degree of resistance indicates the existence of a special survival signal in M1 cells. AURKA acts as a local inhibitor against spontaneous necroptosis, by associating with RIPK3 and RIPK1 in resting cells [30]. In the presence of AURKA inhibitors, M1 cells became as sensitive to TAK1 inhibitor-induced cell death as the M2 cells were. GSK3 $\beta$ was identified as the downstream target of AURKA in the regulation of necroptosis [30], and consequently, GSK3 $\beta$ inhibitors also restored the sensitivity of M1 cells to TAK1 inhibitor-induced cell death. AURKA inhibitors are also intensively studied in tumor therapy [44], but their effect on TME is less intensively investigated. Hereby, we highlight that AURKA may have an effect on the immunosuppressive microenvironment, keeping M1 cells alive, which can be considered in therapeutic approaches using AURKA inhibitors either alone or in co-therapy.

More than 20 drugs, approved mostly in cancer therapy, but also in autoimmune or neurodegenerative disorders, have the potential to regulate necroptosis [18]. How these drugs modify the life span of M1/M2 cells still have not been investigated, but this effect may have influence on the current applications of necroptosis regulators.

Two different types of necroptosis have been detected by TNF induction in $661 \mathrm{~W}$ mouse photoreceptor cell lines. Activation of TNF/5Z-7/Z-VAD resulted in different necroptosis than TNF/CHX/Z-VAD concerning the molecular composition and also the signal transduction of necroptotic pathway [45].

Our results indicate heterogeneous functionality of different necroptotic stimuli, highlighting the importance of specifying and differentiating necroptotic pathways. Overall, our findings provide new approaches to regulate the balance of M1/M2 cells in the treatment for various diseases such as cancer or chronic infections. 
A

B
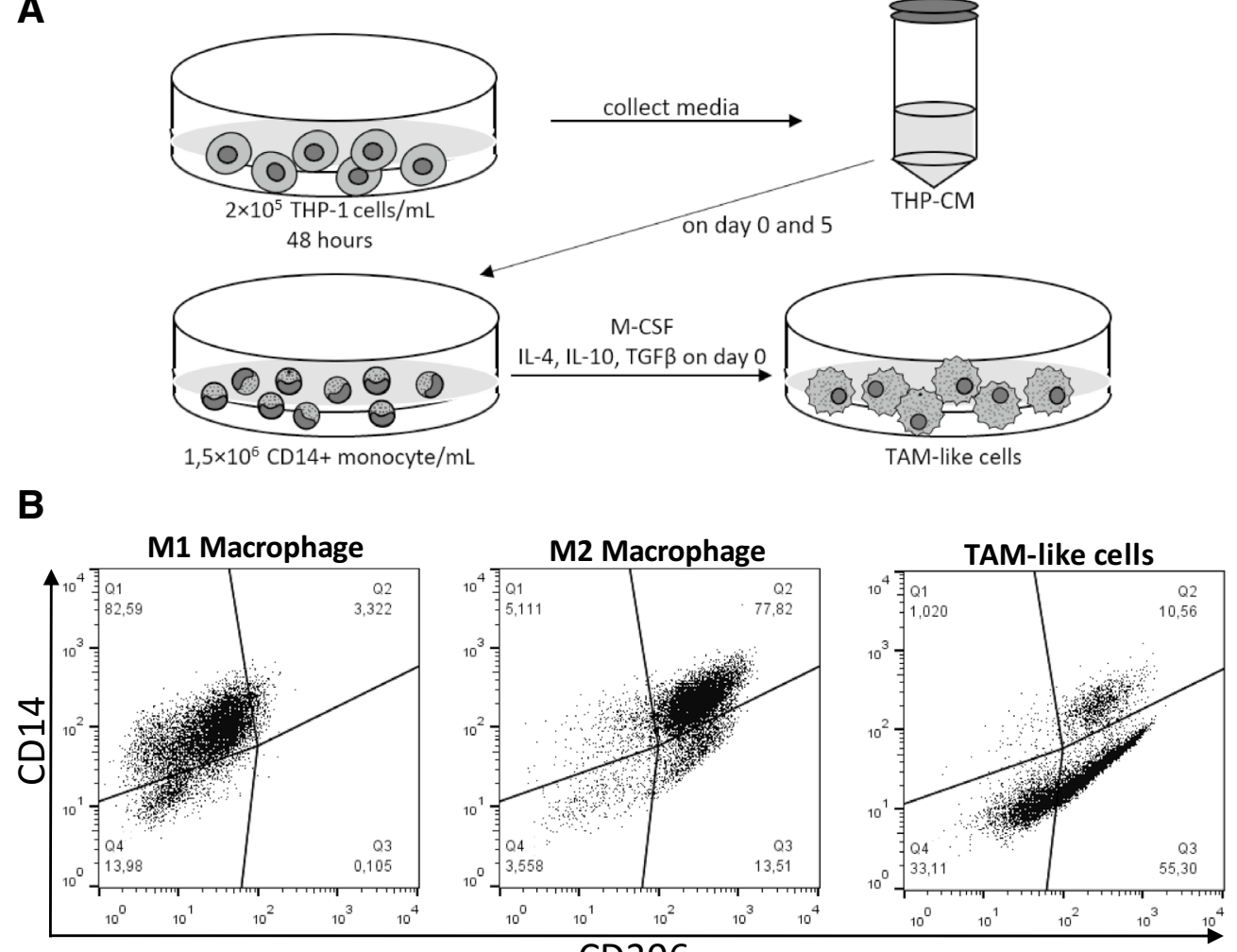

C
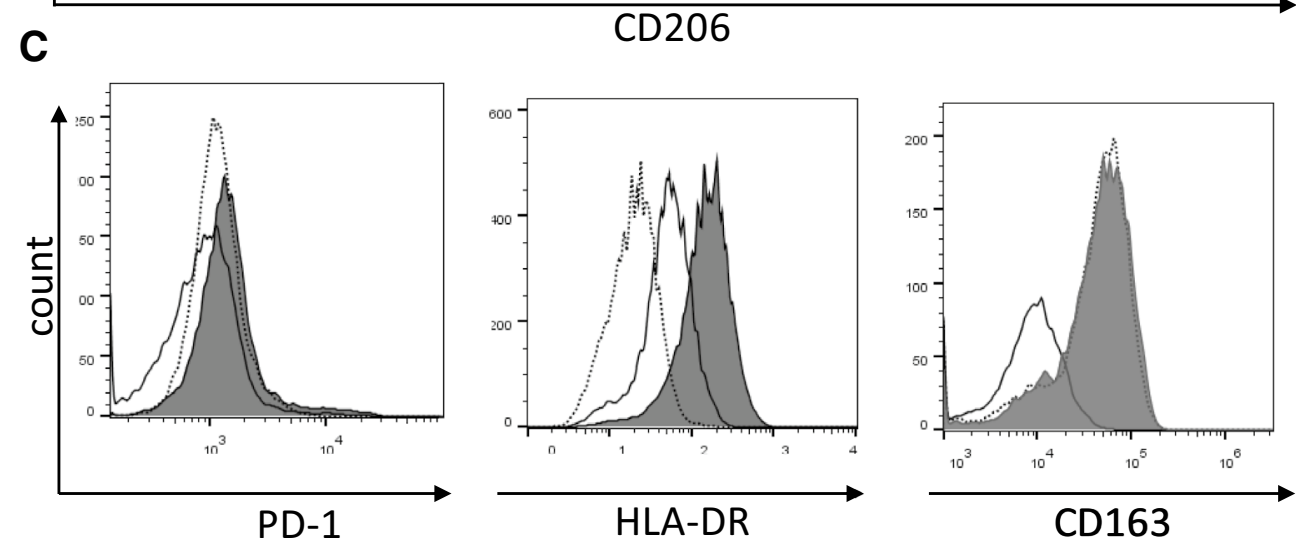

M1

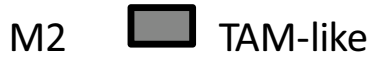

D

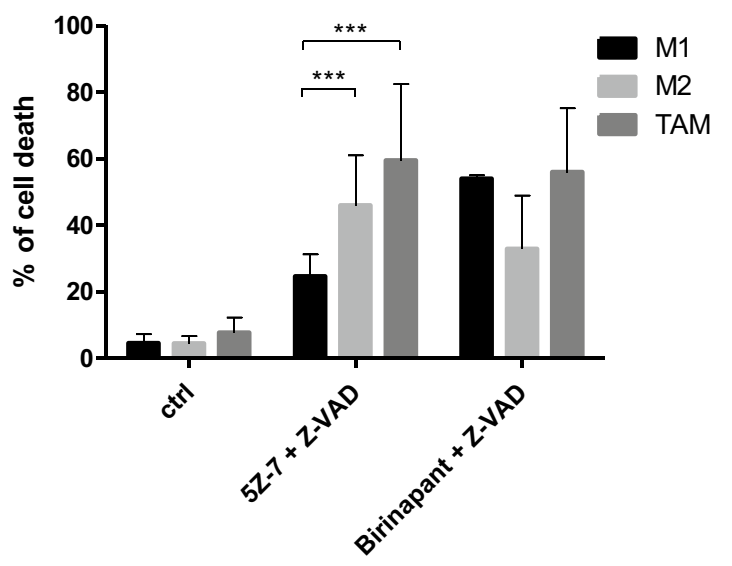


४Fig. 6 TAK1 inhibitor induces necroptosis on TAM-like macrophages. a Schematic of the generation of TAM-like cells. Medium was conditioned on THP- 1 cells for $48 \mathrm{~h}$, and was subsequently collected and centrifuged to remove the THP-1 cells (THP-CM). CD14+ monocytes were harvested from healthy donors and plated at $1.5 \times 10^{6}$ cells $/ \mathrm{ml}$. During TAM-like cell differentiation process, M-CSF, IL-4, IL-10 and TGF $\beta$ cytokines were added to the culture for 5 days in THP-CM. On day 5 the medium was changed to fresh THP-CM. On day 6 the TAM-like cells were harvested. b, $\mathbf{c}$ In vitro generated TAM-like cells were compared to classically and alternatively activated macrophages. Cells were stained and measured on day 6 by flow cytometry to assess surface expression of CD14 and CD206, or CD163, PD-1 and HLA-DR. Representative flow plots and histograms are shown. d The in vitro differentiated human M1, $\mathrm{M} 2$ and TAM-like cells were treated with $0.5 \mu \mathrm{M}$ birinapant or $1 \mu \mathrm{M}$ 5Z-7-oxozeaenol with $50 \mu \mathrm{M}$ Z-VAD. Cell death was quantified by PI staining in $24 \mathrm{~h}$. Figure shows the mean plus SD of at least five independent experiments

Acknowledgements Open access funding provided by University of Debrecen (DE). We thank Zsuzsanna Debreceni for excellent technical assistance. The European Regional Development Fund GINOP-2.3.215-2016-00005, the National Research, Development and Innovation Office - NKFIH, 125224 are acknowledged for financial support of this work.

Author contributions ZSV, TM, AM, RK, VJ and KK performed experiments and were responsible for analysis and interpretation of data. BA was involved in reviewing the manuscript. KG was responsible for conception of the study and wrote the manuscript. All authors revised the manuscript and approved the final version of the manuscript.

\section{Compliance with ethical standards}

Conflict of interest The authors declare no conflict of interests.

Open Access This article is licensed under a Creative Commons Attribution 4.0 International License, which permits use, sharing, adaptation, distribution and reproduction in any medium or format, as long as you give appropriate credit to the original author(s) and the source, provide a link to the Creative Commons licence, and indicate if changes were made. The images or other third party material in this article are included in the article's Creative Commons licence, unless indicated otherwise in a credit line to the material. If material is not included in the article's Creative Commons licence and your intended use is not permitted by statutory regulation or exceeds the permitted use, you will need to obtain permission directly from the copyright holder. To view a copy of this licence, visit http://creativecommons.org/licenses/by/4.0/.

\section{References}

1. Mills CD (2015) Anatomy of a discovery: $\mathrm{m} 1$ and $\mathrm{m} 2 \mathrm{mac}-$ rophages. Front Immunol 6:212. https://doi.org/10.3389/fimmu .2015 .00212

2. Zotes TM, Arias CF, Fuster JJ, Spada R, Perez-Yague S, Hirsch E, Wymann M, Carrera AC, Andres V, Barber DF (2013) PI3K p110gamma deletion attenuates murine atherosclerosis by reducing macrophage proliferation but not polarization or apoptosis in lesions. PLoS ONE 8(8):e72674. https://doi.org/10.1371/journ al.pone. 0072674
3. Liu W, Zhang X, Zhao M, Zhang X, Chi J, Liu Y, Lin F, Fu Y, Ma D, Yin X (2015) Activation in M1 but not M2 macrophages contributes to cardiac remodeling after myocardial infarction in rats: a critical role of the calcium sensing receptor/NRLP3 inflammasome. Cell Physiol Biochem 35(6):2483-2500. https://doi. org/10.1159/000374048

4. Yu T, Zhao L, Huang X, Ma C, Wang Y, Zhang J, Xuan D (2016) Enhanced activity of the macrophage M1/M2 phenotypes and phenotypic switch to M1 in periodontal infection. J Periodontol 87(9):1092-1102. https://doi.org/10.1902/jop.2016.160081

5. Quatromoni JG, Eruslanov E (2012) Tumor-associated macrophages: function, phenotype, and link to prognosis in human lung cancer. Am J Transl Res 4(4):376-389

6. DeNardo DG, Ruffell B (2019) Macrophages as regulators of tumour immunity and immunotherapy. Nat Rev Immunol 19(6):369-382. https://doi.org/10.1038/s41577-019-0127-6

7. Eapen MS, Hansbro PM, McAlinden K, Kim RY, Ward C, Hackett TL, Walters EH, Sohal SS (2017) Abnormal M1/M2 macrophage phenotype profiles in the small airway wall and lumen in smokers and chronic obstructive pulmonary disease (COPD). Sci Rep 7(1):13392. https://doi.org/10.1038/s41598-017-13888-x

8. Verdeguer F, Aouadi M (2017) Macrophage heterogeneity and energy metabolism. Exp Cell Res 360(1):35-40. https://doi. org/10.1016/j.yexcr.2017.03.043

9. Tardito S, Martinelli G, Soldano S, Paolino S, Pacini G, Patane M, Alessandri E, Smith V, Cutolo M (2019) Macrophage M1/ M2 polarization and rheumatoid arthritis: a systematic review. Autoimmun Rev 18(11):102397. https://doi.org/10.1016/j.autre v.2019.102397

10. Quaranta V, Schmid MC (2019) Macrophage-mediated subversion of anti-tumour immunity. Cells 8(7):747. https://doi.org/10.3390/ cells 8070747

11. Parihar A, Eubank TD, Doseff AI (2010) Monocytes and macrophages regulate immunity through dynamic networks of survival and cell death. J Innate Immun 2(3):204-215. https://doi. org/10.1159/000296507

12. Schilling R, Geserick P, Leverkus M (2014) Characterization of the ripoptosome and its components: implications for anti-inflammatory and cancer therapy. Methods Enzymol 545:83-102. https ://doi.org/10.1016/B978-0-12-801430-1.00004-4

13. Griewahn L, Koser A, Maurer U (2019) keeping cell death in check: ubiquitylation-dependent control of TNFR1 and TLR signaling. Front Cell Dev Biol 7:117. https://doi.org/10.3389/ fcell.2019.00117

14. Sanjo H, Nakayama J, Yoshizawa T, Fehling HJ, Akira S, Taki S (2019) Cutting edge: TAK1 safeguards macrophages against proinflammatory cell death. J Immunol 203(4):783-788. https:// doi.org/10.4049/jimmunol.1900202

15. Holler N, Zaru R, Micheau O, Thome M, Attinger A, Valitutti S, Bodmer JL, Schneider P, Seed B, Tschopp J (2000) Fas triggers an alternative, caspase-8-independent cell death pathway using the kinase RIP as effector molecule. Nat Immunol 1(6):489-495. https://doi.org/10.1038/82732

16. He S, Wang L, Miao L, Wang T, Du F, Zhao L, Wang X (2009) Receptor interacting protein kinase- 3 determines cellular necrotic response to TNF-alpha. Cell 137(6):1100-1111

17. Zhao J, Jitkaew S, Cai Z, Choksi S, Li Q, Luo J, Liu Z-G (2012) Mixed lineage kinase domain-like is a key receptor interacting protein 3 downstream component of TNF-induced necrosis. Proc Natl Acad Sci USA 109(14):5322-5327. https://doi.org/10.1073/ pnas.1200012109

18. Molnar T, Mazlo A, Tslaf V, Szollosi AG, Emri G, Koncz G (2019) Current translational potential and underlying molecular mechanisms of necroptosis. Cell Death Dis 10(11):860. https:// doi.org/10.1038/s41419-019-2094-Z 
19. Galluzzi L, Vitale I, Aaronson SA, Abrams JM, Adam D, Agostinis P, Alnemri ES, Altucci L, Amelio I, Andrews DW, Annicchiarico-Petruzzelli M, Antonov AV, Arama E, Baehrecke EH, Barlev NA, Bazan NG, Bernassola F, Bertrand MJM, Bianchi K, Blagosklonny MV, Blomgren K, Borner C, Boya P, Brenner C, Campanella M, Candi E, Carmona-Gutierrez D, Cecconi F, Chan FK, Chandel NS, Cheng EH, Chipuk JE, Cidlowski JA, Ciechanover A, Cohen GM, Conrad M, Cubillos-Ruiz JR, Czabotar PE, D'Angiolella V, Dawson TM, Dawson VL, De Laurenzi V, De Maria R, Debatin KM, DeBerardinis RJ, Deshmukh M, Di Daniele N, Di Virgilio F, Dixit VM, Dixon SJ, Duckett CS, Dynlacht BD, El-Deiry WS, Elrod JW, Fimia GM, Fulda S, Garcia-Saez AJ, Garg AD, Garrido C, Gavathiotis E, Golstein P, Gottlieb E, Green DR, Greene LA, Gronemeyer H, Gross A, Hajnoczky G, Hardwick JM, Harris IS, Hengartner MO, Hetz C, Ichijo H, Jaattela M, Joseph B, Jost PJ, Juin PP, Kaiser WJ, Karin M, Kaufmann T, Kepp O, Kimchi A, Kitsis RN, Klionsky DJ, Knight RA, Kumar S, Lee SW, Lemasters JJ, Levine B, Linkermann A, Lipton SA, Lockshin RA, Lopez-Otin C, Lowe SW, Luedde T, Lugli E, MacFarlane M, Madeo F, Malewicz M, Malorni W, Manic G, Marine JC, Martin SJ, Martinou JC, Medema JP, Mehlen P, Meier P, Melino S, Miao EA, Molkentin JD, Moll UM, Munoz-Pinedo C, Nagata S, Nunez G, Oberst A, Oren M, Overholtzer M, Pagano M, Panaretakis T, Pasparakis M, Penninger JM, Pereira DM, Pervaiz S, Peter ME, Piacentini M, Pinton P, Prehn JHM, Puthalakath H, Rabinovich GA, Rehm M, Rizzuto R, Rodrigues CMP, Rubinsztein DC, Rudel T, Ryan KM, Sayan E, Scorrano L, Shao F, Shi Y, Silke J, Simon HU, Sistigu A, Stockwell BR, Strasser A, Szabadkai G, Tait SWG, Tang D, Tavernarakis N, Thorburn A, Tsujimoto Y, Turk B, Vanden Berghe T, Vandenabeele P, Vander Heiden MG, Villunger A, Virgin HW, Vousden KH, Vucic D, Wagner EF, Walczak H, Wallach D, Wang Y, Wells JA, Wood W, Yuan J, Zakeri Z, Zhivotovsky B, Zitvogel L, Melino G, Kroemer G (2018) Molecular mechanisms of cell death: recommendations of the Nomenclature Committee on Cell Death 2018. Cell Death Differ 25(3):486-541. https://doi.org/10.1038/s41418-017-0012-4

20. Lin Y, Devin A, Rodriguez Y, Liu ZG (1999) Cleavage of the death domain kinase RIP by caspase- 8 prompts TNF-induced apoptosis. Genes Dev 13(19):2514-2526

21. Vanden Berghe T, Kaiser WJ, Bertrand MJ, Vandenabeele P (2015) Molecular crosstalk between apoptosis, necroptosis, and survival signaling. Mol Cell Oncol 2(4):e975093. https://doi. org/10.4161/23723556.2014.975093

22. O'Donnell MA, Perez-Jimenez E, Oberst A, Ng A, Massoumi R, Xavier R, Green DR, Ting AT (2011) Caspase 8 inhibits programmed necrosis by processing CYLD. Nat Cell Biol 13(12):1437-1442

23. Park SM, Yoon JB, Lee TH (2004) Receptor interacting protein is ubiquitinated by cellular inhibitor of apoptosis proteins (c-IAP1 and c-IAP2) in vitro. FEBS Lett 566(1-3):151-156. https://doi. org/10.1016/j.febslet.2004.04.021

24. Wang CY, Mayo MW, Korneluk RG, Goeddel DV, Baldwin AS $\mathrm{Jr}$ (1998) NF-kappaB antiapoptosis: induction of TRAF1 and TRAF2 and c-IAP1 and c-IAP2 to suppress caspase-8 activation. Science 281(5383):1680-1683

25. Micheau O, Lens S, Gaide O, Alevizopoulos K, Tschopp J (2001) NF-kappaB signals induce the expression of c-FLIP. Mol Cell Biol 21(16):5299-5305. https://doi.org/10.1128/ MCB.21.16.5299-5305.2001

26. Guo X, Yin H, Chen Y, Li L, Li J, Liu Q (2016) TAK1 regulates caspase 8 activation and necroptotic signaling via multiple cell death checkpoints. Cell Death Dis 7(9):e2381. https://doi. org/10.1038/cddis.2016.294

27. Dondelinger Y, Jouan-Lanhouet S, Divert T, Theatre E, Bertin J, Gough PJ, Giansanti P, Heck AJ, Dejardin E, Vandenabeele P, Bertrand MJ (2015) NF-kappaB-independent role of IKKalpha/
IKKbeta in preventing RIPK1 kinase-dependent apoptotic and necroptotic cell death during TNF signaling. Mol Cell 60(1):6376. https://doi.org/10.1016/j.molcel.2015.07.032

28. Haas TL, Emmerich CH, Gerlach B, Schmukle AC, Cordier SM, Rieser E, Feltham R, Vince J, Warnken U, Wenger T, Koschny R, Komander D, Silke J, Walczak H (2009) Recruitment of the linear ubiquitin chain assembly complex stabilizes the TNF-R1 signaling complex and is required for TNF-mediated gene induction. Mol Cell 36(5):831-844. https://doi.org/10.1016/j.molcel.2009.10.013

29. Jaco I, Annibaldi A, Lalaoui N, Wilson R, Tenev T, Laurien L, Kim C, Jamal K, Wicky John S, Liccardi G, Chau D, Murphy JM, Brumatti G, Feltham R, Pasparakis M, Silke J, Meier P (2017) MK2 Phosphorylates RIPK1 to prevent TNF-induced cell death. Mol Cell 66(5):698-710 e695. https://doi.org/10.1016/j.molce 1.2017.05.003

30. Xie Y, Zhu S, Zhong M, Yang M, Sun X, Liu J, Kroemer G, Lotze M, Zeh HJ 3rd, Kang R, Tang D (2017) Inhibition of aurora Kinase A induces necroptosis in pancreatic carcinoma. Gastroenterology 153(5):1429-1443 e1425. https://doi.org/10.1053/j.gastr o.2017.07.036

31. Siegmund D, Kums J, Ehrenschwender M, Wajant H (2016) Activation of TNFR2 sensitizes macrophages for TNFR1-mediated necroptosis. Cell Death Dis 7(9):e2375. https://doi.org/10.1038/ cddis. 2016.285

32. Mia S, Warnecke A, Zhang XM, Malmstrom V, Harris RA (2014) An optimized protocol for human M2 macrophages using M-CSF and IL-4/IL-10/TGF-beta yields a dominant immunosuppressive phenotype. Scand J Immunol 79(5):305-314. https://doi. org/10.1111/sji.12162

33. Raggi F, Pelassa S, Pierobon D, Penco F, Gattorno M, Novelli F, Eva A, Varesio L, Giovarelli M, Bosco MC (2017) Regulation of human macrophage M1-M2 polarization balance by hypoxia and the triggering receptor expressed on myeloid cells-1. Front Immunol 8:1097. https://doi.org/10.3389/fimmu.2017.01097

34. Benner B, Scarberry L, Suarez-Kelly LP, Duggan MC, Campbell AR, Smith E, Lapurga G, Jiang K, Butchar JP, Tridandapani S, Howard JH, Baiocchi RA, Mace TA, Carson WE 3rd (2019) Generation of monocyte-derived tumor-associated macrophages using tumor-conditioned media provides a novel method to study tumorassociated macrophages in vitro. J Immunother Cancer 7(1):140. https://doi.org/10.1186/s40425-019-0622-0

35. Lin Y, Xu J, Lan H (2019) Tumor-associated macrophages in tumor metastasis: biological roles and clinical therapeutic applications. J Hematol Oncol 12(1):76. https://doi.org/10.1186/s1304 5-019-0760-3

36. Sawa-Wejksza K, Kandefer-Szerszen M (2018) Tumor-associated macrophages as target for antitumor therapy. Arch Immunol Ther Exp (Warsz) 66(2):97-111. https://doi.org/10.1007/s0000 5-017-0480-8

37. Elliott LA, Doherty GA, Sheahan K, Ryan EJ (2017) Human tumor-infiltrating myeloid cells: phenotypic and functional diversity. Front Immunol 8:86. https://doi.org/10.3389/fimmu .2017 .00086

38. Gordon SR, Maute RL, Dulken BW, Hutter G, George BM, McCracken MN, Gupta R, Tsai JM, Sinha R, Corey D, Ring AM, Connolly AJ, Weissman IL (2017) PD-1 expression by tumourassociated macrophages inhibits phagocytosis and tumour immunity. Nature 545(7655):495-499. https://doi.org/10.1038/natur e22396

39. Nally FK, De Santi C, McCoy CE (2019) Nanomodulation of macrophages in multiple sclerosis. Cells 8(6):543. https://doi. org/10.3390/cells8060543

40. Lagana AS, Salmeri FM, Ban Frangez H, Ghezzi F, VrtacnikBokal E, Granese R (2019) Evaluation of M1 and M2 macrophages in ovarian endometriomas from women affected by 
endometriosis at different stages of the disease. Gynecol Endocrinol. https://doi.org/10.1080/09513590.2019.1683821

41. Fulda S (2017) Smac mimetics to therapeutically target IAP proteins in cancer. Int Rev Cell Mol Biol 330:157-169. https://doi. org/10.1016/bs.ircmb.2016.09.004

42. Sakurai H (2012) Targeting of TAK1 in inflammatory disorders and cancer. Trends Pharmacol Sci 33(10):522-530. https://doi. org/10.1016/j.tips.2012.06.007

43. Park J, Kim HD, Lee SH, Kwak CH, Chang YC, Lee YC, Chung TW, Magae J, Kim CH (2019) Ascochlorin induces caspase-independent necroptosis in LPS-stimulated RAW 264.7 macrophages. J Ethnopharmacol 239:111898. https://doi.org/10.1016/j. jep.2019.111898

44. Tang A, Gao K, Chu L, Zhang R, Yang J, Zheng J (2017) Aurora kinases: novel therapy targets in cancers. Oncotarget 8(14):2393723954. https://doi.org/10.18632/oncotarget.14893
45. Amin P, Florez M, Najafov A, Pan H, Geng J, Ofengeim D, Dziedzic SA, Wang H, Barrett VJ, Ito Y, LaVoie MJ, Yuan J (2018) Regulation of a distinct activated RIPK1 intermediate bridging complex I and complex II in TNFalpha-mediated apoptosis. Proc Natl Acad Sci U S A 115(26):E5944-E5953. https://doi. org/10.1073/pnas.1806973115

Publisher's Note Springer Nature remains neutral with regard to jurisdictional claims in published maps and institutional affiliations. 